\title{
Cleaning the river Damodar (India): impact of COVID-19 lockdown on water quality and future rejuvenation strategies
}

\author{
Baisakhi Chakraborty ${ }^{1}$ - Sambhunath Roy ${ }^{1} \cdot$ Amit Bera $^{2} \cdot$ Partha Pratim Adhikary ${ }^{3}$. \\ Biswajit Bera ${ }^{4}$. Debashish Sengupta ${ }^{5} \cdot$ Gouri Sankar Bhunia ${ }^{6} \cdot$ Pravat Kumar Shit $^{1}$ if
}

Received: 13 August 2020 / Accepted: 9 December 2020 / Published online: 3 January 2021

(c) The Author(s), under exclusive licence to Springer Nature B.V. part of Springer Nature 2021

\begin{abstract}
Globally, it is established that the partial lockdown system assists to improve the health of the total environment due to inadequate anthropogenic actions in different economic sectors. The ample research on fitness of environment has been proved that the strict imposition of lockdown was the blessings of environment. The river Damodar has historical significance and lifeline for huge population of Jharkhand and West Bengal state of India but in the recent years the water quality has been deteriorated due to untreated industrial effluents and urban sewage. The main objective of this study is to examine the water quality of river Damodar during and prelockdown phase for domestic use and restoration of river ecosystem. A total of eleven (11) effluent discharge sites were selected in prelockdown and during lockdown phase. A new approach of water quality assessment, i.e., water pollution index (WPI) has been applied in this study. WPI is weightage free, unbiased method to analysis of water quality. The result shows that the physical, chemical and heavy elements were found beyond the standard limit in prelockdown period. The cation and anion were arranged in an order of $\mathrm{Na}^{2+}>\mathrm{K}^{+}>\mathrm{Ca}^{2+}>\mathrm{Mg}^{2+}$ and $\mathrm{Cl}^{-}>\mathrm{So}_{4}{ }^{-}>\mathrm{No}_{3}{ }^{-}>\mathrm{F}^{-}$ in both the sessions. WPI of prelockdown showed that about $100 \%$ water samples are of highly polluted. WPI of lockdown period showed that around $90.90 \%$ samples improved to 'good quality' and $9.10 \%$ of samples are of 'moderately polluted.' Hypothesis testing by ' $t$ ' test proved that there was a significant difference $(\rho=0.05 \%)$ in values of each parameter between two periods. Null hypothesis was rejected and indicated the improvement of river water quality statistically. Spatial mapping using Arc GIS 10.4 interpolation (IDW) helps to understand spatial intensity of pollution load in two periods. This research study should be helpful for further management and spatial diagnosis of water resource of river Damodar.
\end{abstract}

Keywords Lockdown · Environmental quality $\cdot$ Water pollution index $\cdot$ Spatial diagnosis $\cdot$ Management

Pravat Kumar Shit

shiptpravat2013@gmail.com

Extended author information available on the last page of the article 


\section{Introduction}

The outbreak of CORONAVIRUS disease (COVID-19) mostly affects the global human health, economic lifeline and socio-cultural rhythm. First, the virus was discovered at Wuhan city of China in December 2019 and it spreads rapidly from affected person to another unaffected person through sneezes, coughs, etc. Nearly 210 countries of the world have been affected up to April 2020 through rapid transmission of COVID-19 virus (Yunus et al. 2020). Yet no perfect remedial medicine or vaccine has been discovered till now and thus human body gets seriously exaggerated by severe acute respiratory syndrome (SARS) due to corona virus. On this critical circumstance, world health organization (WHO) suggested to maintain social distancing and mandatory face mask for the people. Most of the countries announced sudden 'lockdown' to avoid public transmission as well as break the infection chain. Worldwide, almost all the sectors have been temporarily clogged during lockdown. In India, 'lockdown' is started from March 25, 2020, by the order of central Government. All the industries are almost closed during this period and thus environment gets unique chance to rid off from huge pollution load released by industries. Though, improvements of environmental quality have been occurred temporarily but it is considered that pollution load was comparatively low with respect to prelockdown period.

Water is one of the very important life supporting components of the environment and it gives energy to all biotic and abiotic elements of the ecosphere and it maintains the environmental equilibrium. This natural resource has been vehemently polluted by various human activities such as industrialization, urbanization, agricultural practice and over exploitation in normal times. But it is examined that pollution level of aquatic environment has been remarkably dropped because of no mixing of industrial waste water, solid waste, heavy metals, etc., during lockdown period (Hader et al. 2020). A recent study on water quality of river Ganga near Kolkata city indicates much higher level of dissolved oxygen (DO) in lockdown period compared to previous years (Dhar et al.2020). Another study on Hooghly estuary near Haldia port, West Bengal demonstrates the enrichment of ichthyoplankton species due to no mixing of industrial waste water and crude oil to the water (Mitra et al. 2020). Investigation on bacterial load as total coliform (TC) on river Ganga at lower course reveals a significant drop of bacterial community in this river ecosystem because no activity of industrial, tourism or traffic sector in lockdown (Mukherjee et al. 2020). The river Ganga (In India) appears very clear and transparent picture at many places during lockdown period (Mani 2020).

Just like river Ganga, another important river Damodar of Chota Nagpur Plateau region is getting huge pollutants from its well developed industrial and urban catchment. Minerals and coal rich Damodar river basin is highly famous for agriculture and industrial growth. Meanwhile, the waste effluents, heavy metals, toxic elements from nearby industries have been discharged into the river and lowering water quality as well as river ecosystem. Many contemporary researches on water quality of Damodar have been conducted through various modern methods and techniques (Tiwari and Dhar 1994; Basu and Mitra, 2002; Tiwari and Abhishek 2005; George et al. 2010; Chatterjee et al. 2010; Banerjee and Gupta 2012; Mukherjee et al. 2012). These relevant studies (physical, chemical or biological assessment) were conducted through popular methods such as water quality index (WQI), pollution load index (PLI), enrichment factor (EF), aseptic techniques (microbial analysis), descriptive statistics, etc. WQI is commonly applied by researchers to evaluate the water quality. It was initially developed by Horton (1965) with using 12 common physical, chemical and biological parameters $(\mathrm{pH}$, electrical conductivity, temperature, turbidity, total 
suspended solids, alkalinity, chloride, nitrate, total phosphate, biological oxygen demand, dissolved oxygen, coliform). But there are some limitations in this method. Similarly, WQI is calculated by giving unequal weightage on the basis of its importance to overall water quality (Pesce and Wunderlin 2000; Liou et al. 2004; Tsegaye et al. 2006). If any parameter of lower concentration was assigned by higher weightage, it could lead to wrong interpretation on final results of WQI (Swamee and Tyagi 2000; Juwana et al. 2012). Another two methods for assessing water quality are heavy metal pollution index (HPI) and integrated water quality index (IWQI) and it mainly identifies metal pollution of the water. HPI is also based on weightage method (Mohan et al. 1996). IWQI is a new approach to determine water quality (Mukate et al. 2019). Both of these two methods are followed highest desirable limit and maximum permissible limit of parameters concentration. On the other hand, BIS (2012) and WHO (2011) generally suggest maximum permissible limit with no highest or lowest limit. Therefore, HPI and IWQI methods usually become inappropriate by using BIS and WHO standards (Chaturvedi et al. 2018).

Thus, to avoid the difficulties of weightage and sensitivity of indexing, there has been emerged a new concept of water quality analysis, i.e., water pollution index (WPI). It is very flexible index method which deals with large number of parameters as physical, chemical ions, heavy metals or even microbial components without putting any weightage. For this convenience, there are no needs to calculate of WQI or HPI separately (Hossain and Patra, 2020).

In the present study, the objective is mainly to evaluate changes of surface water quality in respect of physical, chemical and heavy trace metals for some selected industrial effluent discharge sites of river Damodar during lockdown period using WPI method and GIS technology.

\section{Study area}

Damodar is originated from khamarpat hill of Jharkhand state, India. Total length of this river is $563 \mathrm{~km}$ before confluence with river Bhagirathi-Hooghly. The source region of this river is highly enriched with high quality coal and minerals reserve like iron, copper, limestone, etc. Availability of mineral resources, water supply and cheap labor attract large scale industrial growth in this region. Many industries along with cities and towns have been established in both side of river Damodar. The present study is confined between Panchet dam ( $\left.23^{\circ} 40^{\prime} 50^{\prime \prime} \mathrm{N} / 86^{\circ} 44^{\prime} 49^{\prime \prime} \mathrm{E}\right)$ and Durgapur barrage (23 $\left.40^{\prime} 50^{\prime \prime} \mathrm{N} / 87^{\circ} 18^{\prime} 39^{\prime \prime} \mathrm{E}\right)$ on a length of $65.37 \mathrm{~km}$ (Fig. 1). The water bodies of this zone are highly polluted by many industrial effluents from nearby iron plant, thermal power plant, sponge iron factory, coal washeries, chemical industries, cement industries. Many small channels locally called 'nalla' which are used as waste or industrial effluents disposal corridors to the main river.

\section{Materials and methods}

\subsection{Procedures of sample collection and analysis}

Water samples were collected from eleven (11) discharge sites of industrial effluents on both side of river Damodar in prelockdown and lockdown period (December 2019) and again during lockdown period (July 2020) for the evaluation of changes of water quality 


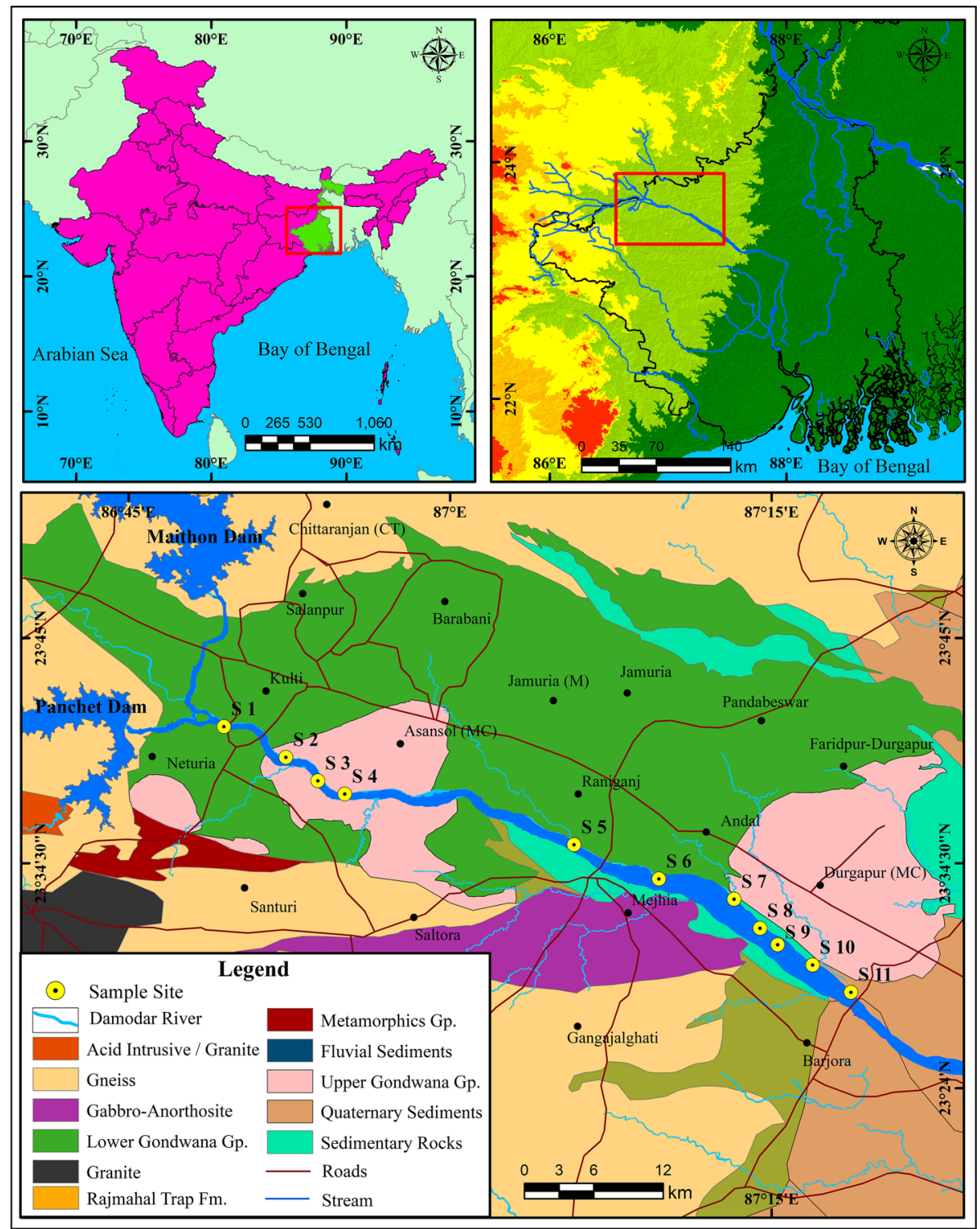

Fig. 1 Location and sampling sites of the study area

(Fig. 1). These samples were obtained from $0.5 \mathrm{~m}$ depth of surface water within $5 \mathrm{~m}$ radius of influence point. Five samples were collected at each site and these are mixed for bulk amount (1 lit). Sample locations were recorded using portable GPS handler (GARMIN GPS). All samples were preserved in pre-cleaned polyethylene bottles $(500 \mathrm{ml})$ and properly carried to laboratory for analysis.

Physical parameters such as $\mathrm{pH}$ and EC were measured in situ by their portable meter (Hanna HI9811-5). TDS was measured as suggested by Hem (1991). 
Chemical parameters like cations $\left(\mathrm{Ca}^{2+}, \mathrm{Mg}^{2+}, \mathrm{K}^{+}, \mathrm{Na}^{2+}\right)$ and anions $\left(\mathrm{F}^{-}, \mathrm{Cl}^{-}, \mathrm{No}_{3}{ }^{-}, \mathrm{So}_{4}{ }^{-}\right)$ were estimated by ion chromatography ( 883 Basic IC plus). Concentration of heavy metals such as $\mathrm{Cd}, \mathrm{Zn}, \mathrm{Pb}, \mathrm{Cu}, \mathrm{Ni}$, and $\mathrm{Fe}$ was primarily in concentrated $\mathrm{Hco}_{3}{ }^{-}(\mathrm{pH}<2)$ for next analysis. All metals were analyzed by Anodic Stripping Voltammetry (VA797, Switzerland) with three different pulse analyzer in a Hanging Mercury Drop electrode (3 M-KCL). Personal computer (Windows) was used for recorded peak of voltammetric analysis.

\subsection{Calculation of water pollution index (WPI)}

Around 17 parameters were analyzed by water pollution index (WPI) method and it is a new approach of water quality analysis. Applying standard permissible limits of WHO (2011), different parameters have been analyzed. Similarly, WPI of river Damodar has been used following the steps (Hossain and Patra 2020).

At first, $\mathrm{PL}_{i}$ (Pollution Load) of each parameter was calculated as following:

$$
\mathrm{PL} i=1+\left(\frac{C_{i}-S_{i}}{S_{i}}\right)
$$

where, Ci means measured concentration of $i$ th parameter, $S_{i}$ means standard limit of permissible for $i$ th parameter. Hossain and Patra (2020) suggest a different formula for calculation of $\mathrm{PL} i$ for $\mathrm{pH}$ by following:

$$
\mathrm{PL} i=\frac{C_{i}-7}{S_{i a}-7}
$$

where, $\mathrm{pH}$ concentration is $<7$, there $S_{i a}$ would be minimum permissible limit of $\mathrm{pH}$, i.e., 6.5. If, $\mathrm{pH}$ concentration is $>7$ then $\mathrm{Sib}$ would be minimum permissible limit of $\mathrm{pH}$, i.e., 8.5 applying following equation:

$$
\mathrm{PL} i=\frac{C_{i}-7}{S_{i b}-7}
$$

Overall WPI were calculated by summation of all values of PL $i$ of $n$ parameter and finally divided by $n$ (no. of parameters). The WPI values were classified based on $\mathrm{n}$ number of parameter into four categories (Table 1).

$$
\mathrm{WPI}=\frac{1}{n} \sum_{i=1}^{n} \mathrm{PL} i
$$

All WPI values of pre-lockdown and during lockdown were interpolated using inverse distance weightage method (IDW) in Arc.GIS platform for showing spatial distribution of water quality on river Damodar.

Table 1 Classification of WPI

\begin{tabular}{ll}
\hline WPI value & Category \\
\hline$<0.5$ & Excellent water \\
$0.5-0.75$ & Good water \\
$0.75-1$ & Moderately polluted water \\
$>1$ & Highly polluted water \\
\hline
\end{tabular}


Difference between water quality of pre-lockdown and lockdown period were analyzed by descriptive statistics, Pearson's correlation analysis, and ' $T$ ' test using SPSS 16 software.

\section{Result and discussion}

\subsection{Hydrochemistry of water samples of river Damodar}

Descriptive statistics and correlation matrix of water samples has been presented for prelockdown period (Tables 2 and 3) and during lockdown period (Table 4). In prelockdown period $\mathrm{pH}$ ranged from 7.04 to 8.21 . During lockdown very low mixing of liquid effluents from industries helps to decrease $\mathrm{pH}$ level of river water and it ranged from 6.12 to 7.72. TDS and EC are directly related to each other as increasing of dissolved solids rises electrical conductivity power of water body. In prelockdown period, TDS was very high due to high amount of mixing of waste materials to the river bed which is increased solubility of soil in the water. TDS in prelockdown ranged from 665.6 to $806.4 \mathrm{mg} / \mathrm{l}$ and from 480 to $563.2 \mathrm{mg} / \mathrm{l}$ during lockdown period. EC ranged from 1040 to $1260 \mu \mathrm{S} / \mathrm{cm}$ in prelockdown period and from 750 to $880 \mu \mathrm{S} / \mathrm{cm}$ during lockdown period. All values of these physical parameters were higher than their standard limit of permissible according to WHO (2011) guidelines in prelockdown session and lower in lockdown session.

Major cations such as $\mathrm{Ca}^{2+}, \mathrm{Na}^{2+}, \mathrm{Mg}^{2+}, \mathrm{K}^{+}$were found very high amount in all samples of prelockdown period as guided by WHO (2011). In this period, mean cation concentration of river water was in a sequence of $\mathrm{Na}^{2+}>\mathrm{K}^{+}>\mathrm{Ca}^{2+}>\mathrm{Mg}^{2+}$. Regular depositions

Table 2 Descriptive statistics of parameters in prelockdown and during lockdown period

\begin{tabular}{|c|c|c|c|c|c|}
\hline & \multicolumn{2}{|l|}{ Prelockdown } & \multicolumn{2}{|c|}{ During lockdown } & \multirow{2}{*}{$\begin{array}{l}\text { WHO } \\
\text { guidelines } \\
(2011)\end{array}$} \\
\hline & Range & Mean $\pm S D$ & Range & Mean $\pm S D$ & \\
\hline $\mathrm{pH}$ & $7.04-8.21$ & $7.45 \pm 0.37$ & $6.12-7.72$ & $6.92 \pm 0.48$ & $6.5-8.5$ \\
\hline TDS (mg/l) & $665.6-806.4$ & $740.65 \pm 50.23$ & $480-563.2$ & $524.85 \pm 26.29$ & 500 \\
\hline $\mathrm{EC}(\mu \mathrm{g} / \mathrm{l})$ & $1040-1260$ & $1157.27 \pm 78.49$ & $750-880$ & $820.09 \pm 41.09$ & 750 \\
\hline $\mathrm{Ca}^{2+}(\mathrm{mg} / \mathrm{l})$ & 94-194 & $131.09 \pm 34.13$ & $50-79$ & $64.81 \pm 9.48$ & 75 \\
\hline $\mathrm{Mg}^{2+}(\mathrm{mg} / \mathrm{l})$ & $50-85$ & $70.36 \pm 11.00$ & $22-32$ & $27 \pm 3$ & 50 \\
\hline $\mathrm{Na}^{2+}(\mathrm{mg} / \mathrm{l})$ & $430-560$ & $500 \pm 42.66$ & $76-120$ & $95.09 \pm 12.12$ & 200 \\
\hline $\mathrm{K}^{+}(\mathrm{mg} / \mathrm{l})$ & $210-380$ & $278.18 \pm 59.96$ & $57-99$ & $81.45 \pm 12.71$ & 200 \\
\hline $\mathrm{So}_{4}{ }^{2-}(\mathrm{mg} / \mathrm{l})$ & $300-410$ & $358.18 \pm 41.18$ & $70-170$ & $127.27 \pm 34.37$ & 250 \\
\hline $\mathrm{Cl}^{-}(\mathrm{mg} / \mathrm{l})$ & $290-480$ & $407.27 \pm 65.12$ & $170-220$ & $198.18 \pm 17.21$ & 250 \\
\hline $\mathrm{No}_{3}{ }^{-}(\mathrm{mg} / \mathrm{l})$ & $75-110$ & $86.45 \pm 9.59$ & $21-47$ & $35.18 \pm 8.53$ & 45 \\
\hline $\mathrm{F}^{-}(\mathrm{mg} / \mathrm{l})$ & $1.6-2.2$ & $1.96 \pm 0.18$ & $0.14-1.11$ & $0.71 \pm 0.34$ & 1.5 \\
\hline $\mathrm{Zn}^{2+}(\mu \mathrm{g} / \mathrm{l})$ & $3200-4700$ & $3984.54 \pm 628.03$ & $1200-1840$ & $1593.63 \pm 201.90$ & 3000 \\
\hline $\mathrm{Cd}^{2+}(\mu \mathrm{g} / \mathrm{l})$ & $12.2-19.45$ & $16.20 \pm 2.85$ & $1.2-2.6$ & $2 \pm 0.44$ & 3 \\
\hline $\mathrm{Pb}^{2+}(\mu \mathrm{g} / \mathrm{l})$ & $18-33$ & $26.18 \pm 5.23$ & $3.4-7.9$ & $5.80 \pm 1.52$ & 10 \\
\hline $\mathrm{Cu}^{2+}(\mu \mathrm{g} / \mathrm{l})$ & $1600-2700$ & $2343.63 \pm 370.60$ & $840-1600$ & $1090.90 \pm 281.33$ & 2000 \\
\hline $\mathrm{Ni}^{2+}(\mu \mathrm{g} / \mathrm{l})$ & $140-230$ & $184.54 \pm 33.57$ & $34-65$ & $51.72 \pm 9.26$ & 70 \\
\hline Total Fe $(\mu \mathrm{g} / \mathrm{l})$ & 1130-1900 & $1618.81 \pm 262.73$ & $120-250$ & $207 \pm 45.95$ & 300 \\
\hline
\end{tabular}




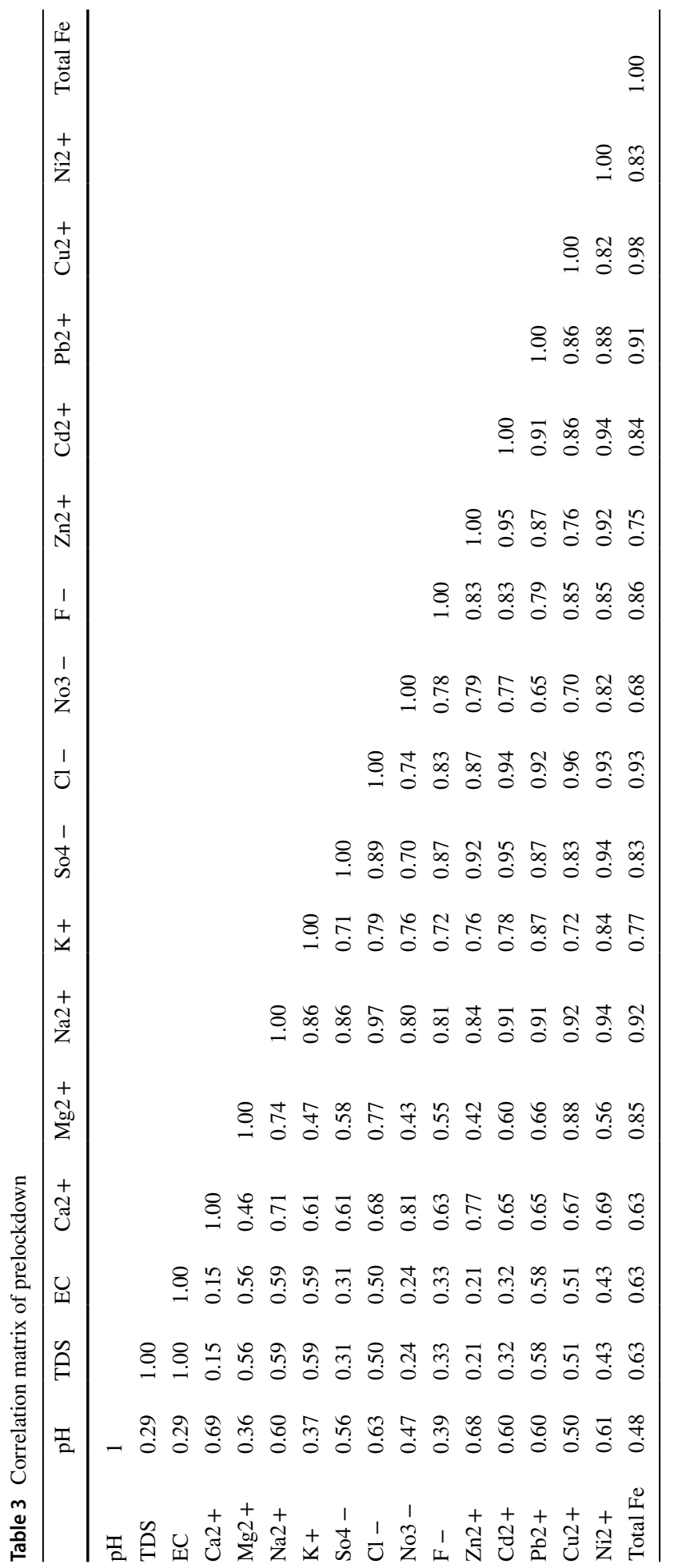




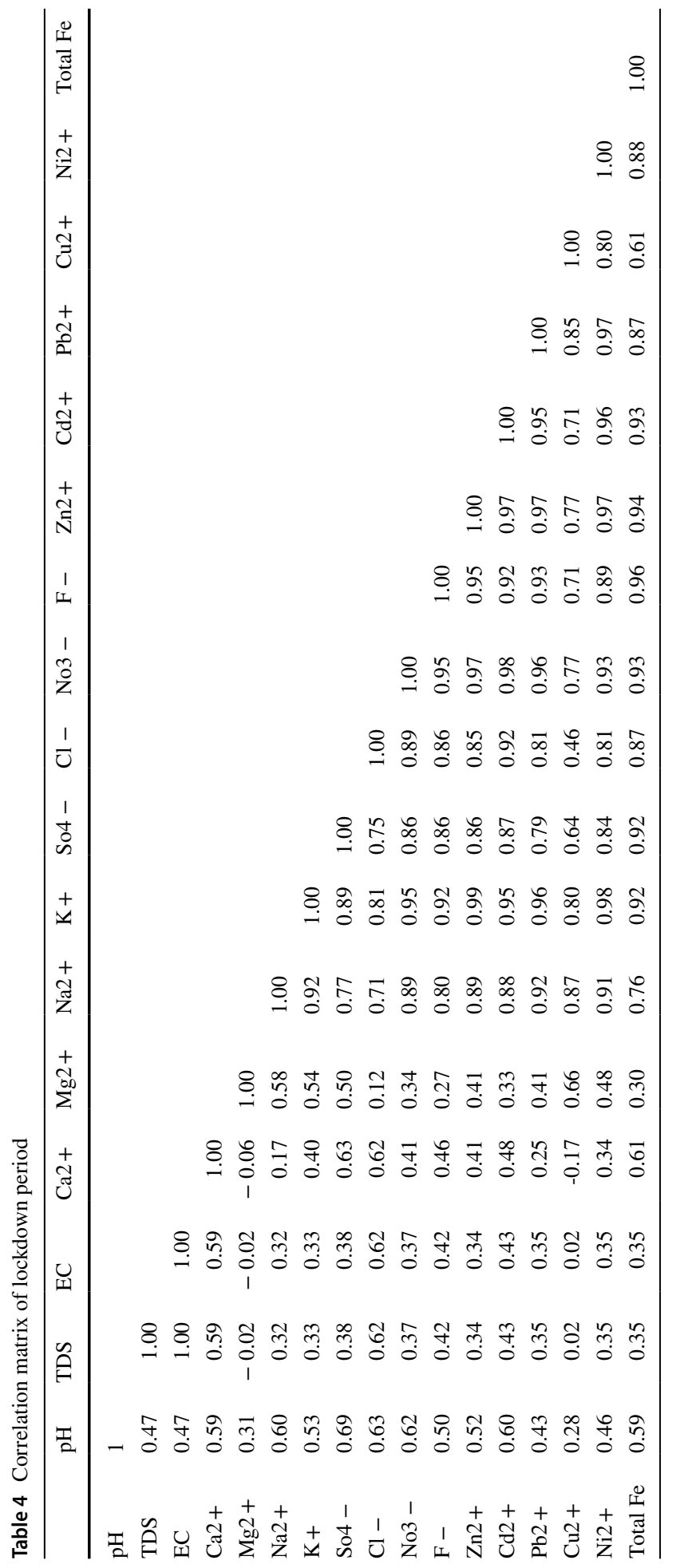


of waste effluents from nearby chemical industries are the main cause of high mixing of sodium and potassium. In lockdown period temporary stopping of industrial activities effectively decreased level of these chemical ions after few months. In this period, it was noticed all of these parameters lowered down than their standard limit (WHO 2011). During lockdown mean value of cations was arranged same as prelockdown.

Major anions as $\mathrm{So}_{4}{ }^{-}, \mathrm{Cl}^{-}, \mathrm{No}_{3}{ }^{-}$and $\mathrm{F}^{-}$are very important determinant of water quality. In pre-monsoon session, all parameters were higher than permissible limit. In this session anions were arranged as an order of $\mathrm{Cl}^{-}>\mathrm{So}_{4}{ }^{-}>\mathrm{No}_{3}{ }^{-}>\mathrm{F}^{-}$. Effluents from nearby cement factory, sponge iron factory are the main factors of high concentration of chloride and sulfate in sample water. During lockdown all of these parameters were found very low amount in river water and all of them were in safe limit.

Mean concentration of heavy metals in river water was in the order of $\mathrm{Zn}^{2+}>\mathrm{Cu}^{2+}>\mathrm{Fe}>\mathrm{Ni}^{2+}>\mathrm{Pb}^{2+}>\mathrm{Cd}^{2+}$ in both prelockdown and lockdown period. Higher concentration of zinc, copper, ferrous indicated higher deposition of solid and liquid materials from nearby iron and steel industries, thermal plant in the bank of river Damodar. According to WHO (2011), most of the samples were above permissible limit of concentration in this session. During lockdown, no mixing of industrial toxic elements helps to decrease the level of heavy metals in river water and indicated their concentration under permissible limit set by WHO (2011).

\subsection{Hypothesis testing ( $T$ test)}

Hypothesis testing was done by ' $T$ ' test to understand whether there were any changes in individual water quality parameter between prelockdown and lockdown period or not. Statistical analysis of ' $T$ ' test showed that around 17 parameters indicated their $T$ value greater than table value at $0.05 \%$ level of significance (Table 5). Thus, rejection of null hypothesis $\left(H_{0}\right)$ strongly suggested that there has significantly reduced the concentration of parameters and improvement of water quality at the study area due to temporarily closing of industries.

\subsection{Status of Damodar water analyzed by water pollution index (WPI)}

On the basis of sample collection from 11 discharge points of industrial effluents at different stretches of river Damodar (on prelockdown and lockdown period), WPI have been done using standard permissible limit of 17 different parameters prescribed by WHO (2011). In prelockdown period, WPI ranged from 1.59 to 2.46 with mean value of 2.07 (Table 6). All samples (100\%) are indicated the high level of pollution in this session. Highest WPI value was found in $S 10$ location. Toxic pollutants are directly discharged into the river and these toxic elements are regularly released from nearby chemical industry. During lockdown period, closing of all types of heavy industries significantly help to reduce pollution level of river water. Near about three months of industrial inactivity brought no such waste effluents to the river bed. WPI values of this session showed very noticeably and ranged from 0.52 to 0.78 with mean value of 0.66 . In this period, around $90.90 \%$ of samples indicated 'good water' type and $9.10 \%$ samples indicated 'moderately polluted water' category (Table 7).

For the identification of spatial distribution of water quality in the river stretch was determined by applying interpolation technique (IDW) using Arc.GIS10.4 software and is presented in Fig. 2. 
Table 5 Values of ' $T$ ' test for hypothesis testing

\begin{tabular}{|c|c|c|}
\hline Parameter & 't $t$-value & $P$ value (\%) \\
\hline $\mathrm{pH}$ & 3.105424 & 0.05 \\
\hline TDS (mg/l) & 12.34664 & 0.05 \\
\hline $\mathrm{EC}(\mu \mathrm{g} / \mathrm{l})$ & 12.34664 & 0.05 \\
\hline $\mathrm{Ca}^{2+}(\mathrm{mg} / \mathrm{l})$ & 6.412227 & 0.05 \\
\hline $\mathrm{Mg}^{2+}(\mathrm{mg} / \mathrm{l})$ & 13.87425 & 0.05 \\
\hline $\mathrm{Na}^{2+}(\mathrm{mg} / \mathrm{l})$ & 41.18781 & 0.05 \\
\hline $\mathrm{K}^{+}(\mathrm{mg} / \mathrm{l})$ & 13.30681 & 0.05 \\
\hline $\mathrm{So}^{4-}(\mathrm{mg} / \mathrm{l})$ & 102.5283 & 0.05 \\
\hline $\mathrm{Cl}^{-}(\mathrm{mg} / \mathrm{l})$ & 13.78952 & 0.05 \\
\hline $\mathrm{No}_{3}{ }^{-}(\mathrm{mg} / \mathrm{l})$ & 30.93489 & 0.05 \\
\hline $\mathrm{F}^{-}(\mathrm{mg} / \mathrm{l})$ & 17.2788 & 0.05 \\
\hline $\mathrm{Zn}^{2+}(\mathrm{mg} / \mathrm{l})$ & 17.30211 & 0.05 \\
\hline $\mathrm{Cd}^{2+}(\mathrm{mg} / \mathrm{l})$ & 19.32441 & 0.05 \\
\hline $\mathrm{Pb}^{2+}(\mathrm{mg} / \mathrm{l})$ & 17.63277 & 0.05 \\
\hline $\mathrm{Cu}^{2+}(\mathrm{mg} / \mathrm{l})$ & 13.48275 & 0.05 \\
\hline $\mathrm{Ni}^{2+}(\mathrm{mg} / \mathrm{l})$ & 17.35355 & 0.05 \\
\hline Total Fe (mg/l) & 21.43122 & 0.05 \\
\hline
\end{tabular}

Table 6 WPI values of sample water in the study area

\begin{tabular}{lllll}
\hline Sample location & $\begin{array}{l}\text { Prelockdown } \\
\text { WPI }\end{array}$ & Quality & $\begin{array}{l}\text { During lockdown } \\
\text { WPI }\end{array}$ & Quality \\
\hline S1 & 1.59 & Highly polluted water & 0.57 & Good water \\
S2 & 1.64 & Highly polluted water & 0.53 & Good water \\
S3 & 1.83 & Highly polluted water & 0.63 & Good water \\
S4 & 1.94 & Highly polluted water & 0.60 & Good water \\
S5 & 2.02 & Highly polluted water & 0.65 & Good water \\
S6 & 2.15 & Highly polluted water & 0.67 & Good water \\
S7 & 2.25 & Highly polluted water & 0.70 & Good water \\
S8 & 2.30 & Highly polluted water & 0.72 & Good water \\
S9 & 2.35 & Highly polluted water & 0.74 & Good water \\
S10 & 2.46 & Highly polluted water & 0.78 & Moderately \\
& & & & polluted \\
& & & water
\end{tabular}

\section{Future river rejuvenation strategies}

The COVID-19 lockdown gave clear indication about environmental deterioration caused by various anthropogenic actions throughout the year. It is confirmed that lockdown method is a temporary measures to avoid pandemic situation. Regeneration of industrial activities is very crucial to overcome economic distress and maintenance of public livelihood. As a result, sustainable livelihood should be practiced for the 
Table 7 Percentage (\%) of sample under different water pollution index (WPI) category

\begin{tabular}{lllll}
\hline & \multicolumn{2}{l}{ Category } & & \\
\cline { 2 - 5 } & $\begin{array}{l}\text { excellent } \\
\text { water }\end{array}$ & Good water & $\begin{array}{l}\text { Moderately } \\
\text { polluted water }\end{array}$ & $\begin{array}{l}\text { Highly } \\
\text { polluted } \\
\text { water }\end{array}$ \\
\hline $\begin{array}{l}\text { Prelockdown } \\
(\% \text { of } \\
\text { samples })\end{array}$ & 0 & 0 & 0 & 100 \\
$\begin{array}{c}\text { During } \\
\text { lockdown } \\
(\% \text { of } \\
\text { samples })\end{array}$ & 0 & 90.90 & 9.10 & \\
\hline
\end{tabular}

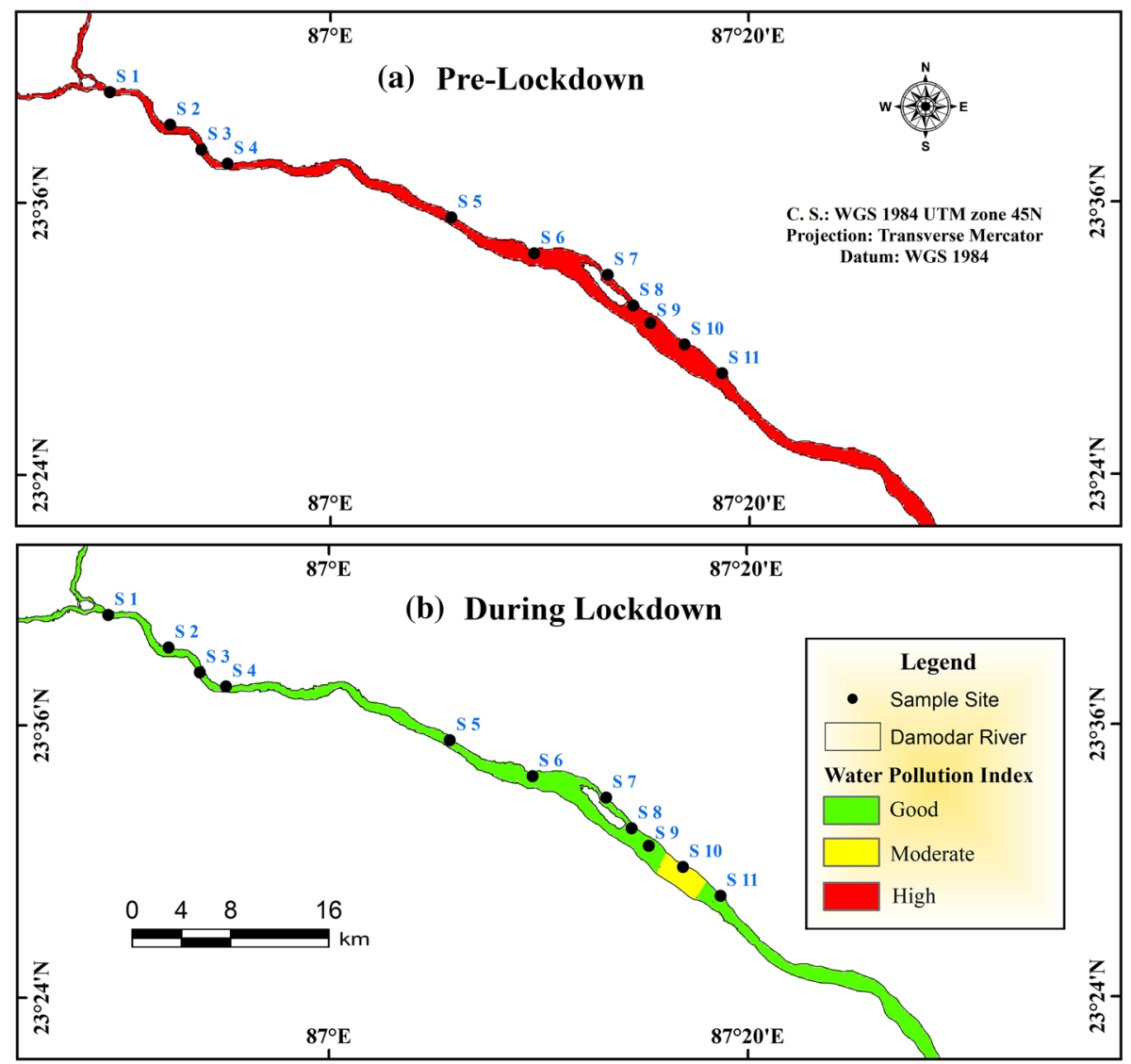

Fig. 2 Spatial variation of river water pollution index (a) Prelockdown phase and (b) During lockdown phase

maintenance of the health of the total environment. To rejuvenate the health of the river Damodar, few relevant remedial measures should be taken. The following mitigation strategies are given below. 


\subsection{Requirement of more rigid regulatory controls}

Stringent quality regulation and enforcement are necessary to verify the incompliance related to wastewater treatment and discharge. The state pollution control board is not equipped to handle this and a new system may be developed. Third-party compliance verification against stipulated environmental norms is highly required and industries must bring in more efficiency and transparency.

\subsection{Integrated river basin management}

The geological, geomorphological, hydrological, pedological, environmental and sociocultural aspects should be considered to ameliorate the health of the river system for domestic and industrial water use. Most of the townships like Raniganj, Durgapur, Asansol, Mejia, Barjora, Panagarh, Burdwan, etc., depend on river Damodar primarily for drinking water. These municipal corporations should install waste water treatment plant and after scientific treatment, water may be discharge into the river system. As a result ecological flow of river water will sustain throughout the year for the survival of aquatic species.

\subsection{Reduction the burden of water abstraction}

A holistic strategy is required to comprehensively control the old canal networks, tributaries and storages in order to pick up the water use effectiveness and irrigation benefits. This would recover the dry season river ecological flow.

\subsection{Scientific waste disposal pits and implementation of environmental policies and acts}

Scientific land use model should be applied for the industrial belt within the river basin and waste disposal pits (for solid/liquid) should be excavated near river bank and riparian wetland for the industries and urban municipal corporations (Fig. 3). Various government policies and environmental regulations such as water (prevention and control of pollution) Act 1974, environment protection act, 1971 should be strictly maintained for the restoration of river water quality specifically for the middle stretch of Damodar river. The environmental, social awareness and community awareness programmes are imperative steps for the management and conservation of river health restoration.

\section{Conclusion}

The water quality as well as river ecosystem of Damodar has been deteriorated for last three to four decades. In the recent years, many applied research on water quality had been conducted and they have brought the reasons behind the deterioration of water quality such as urban sewage and discharge of industrial effluents from the iron and steel industries, chemical, cement, tannery industry, thermal power plant. The contemporary research highlighted that industrial waste effluents are directly thrown into the river water without treatment ( Bhattacharyya et al. 2013; Sundararanjan and Mohan 2011; 


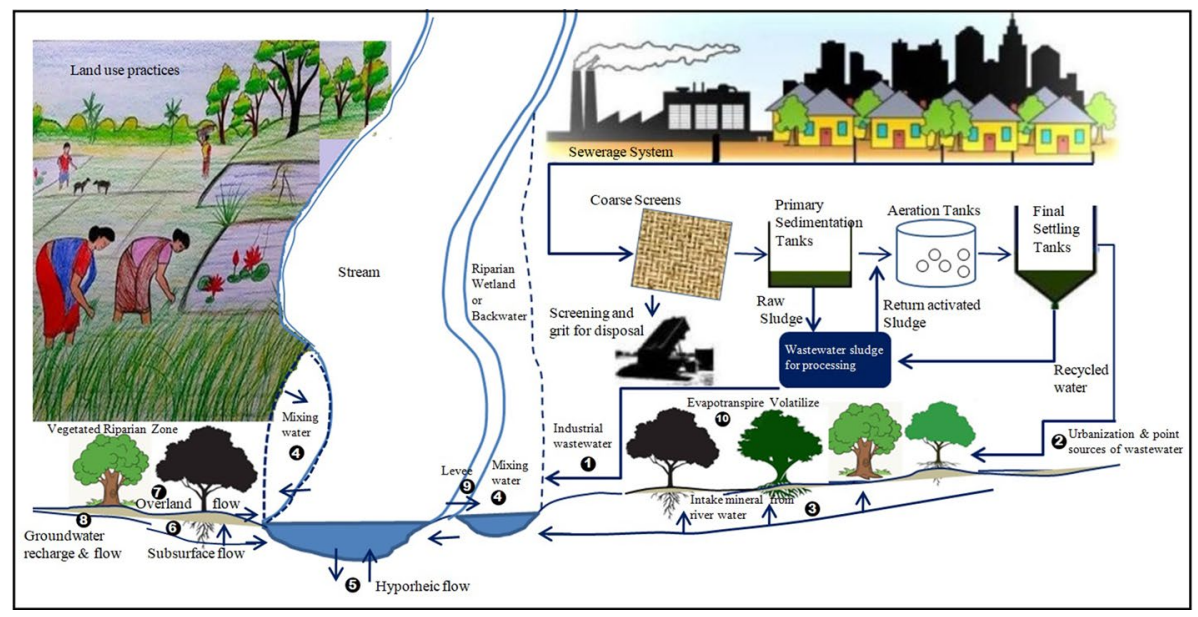

Fig. 3 Schematic diagram of restoration pathways of improving water quality

Ghosh and Banerjee, 2012; Singh et al. 2014; Chatterjee et al. 2010; George et al. 2010; Mukherjee et al. 2012). Here, the current study focused that the physical, chemical and heavy metals have been found beyond permissible limit (WHO, 2011) at effluents discharge sites in the present study.

In this study, assessment on difference of water quality between prelockdown and during lockdown of COVID-19 was conducted through a new approach, i.e., WPI as suggested by Hossain and Patra, 2020. WPI of prelockdown showed that around 100\% samples are of highly polluted. During lockdown a significant development has been noticed in river water. WPI of lockdown showed that around $90.90 \%$ samples are of good and around $9.10 \%$ samples are of moderately polluted.

Thus, various awareness programmes should be practiced by local governing bodies. From this research work on impact of lockdown to improvement of river water quality would be helpful for further management, restoration and spatial treatment of river water towards the achievement of environmental sustainability.

Acknowledgements The authors show their kind acknowledgment to the Dept. of Geography and Microbiology, Raja N. L. Khan Women's College (Autonomous), Department of Earth Sciences, Indian Institute of Engineering Science and Technology (IIEST), Shibpur, West Bengal, and Department of Geology \& Geophysics, Indian Institute of Technology (IIT), Kharagpur, West Bengal, India, for their laboratory facilities and kind encouragement.

Author contributions P.K. Shit conceptualized and planned the study and reviewed and edited the manuscript. B. Chakraborty conducted the survey, water sampling, analyzed the data, and interpreted the results. S. Roy conducted the survey and prepared the maps. A. Bera conducted the survey and analyzed the data. P.P. Adhikary reviewed and edited the manuscript. B. Bera supervised the study and reviewed and edited the manuscript. D. Sengupta supervised the overall research, and interpreted the results. G.S. Bhunia interpreted the results. All authors have read and approved the final manuscript.

Funding This research was supported by the Department of Geography, Raja N. L. Khan Women's College (Autonomous), affiliated to Vidyasagar University, Midnapore, West Bengal, India. The author (P. K. Shit) grateful acknowledges West Bengal DSTBT for financial support through R\&D Research Project Memo no. 104(Sanc.)/ST/P/S\&T/ 10G-5/2018). 


\section{Compliance with ethical standards}

Conflict of interest No potential conflict of interest was reported by the author(s).

\section{References}

Banerjee, U. S., \& Gupta, S. (2013). Impact of industrial waste effluents on river Damodar adjacent to Durgapur industrial complex West Bengal India. Environment Monitering and Assessment. https://doi. org/10.1007/s10661-012-2690-1.

Basu, M., \& Mitra, A. K. (2002). Studies on the pollution of river Damodar at Burdwan with special reference to metals COD and pH. Nature Environment and Pollution Technology, 1(4), 397-400.

Bhattacharyya, R., Kumar, M., \& Kumar, P. P. (2013). Index analysis, graphical and multivariate statistical approaches for hydrochemical characterisation of Damodar River and its canal system Durgapur West Bengal India. International Research of Journal and Environment Science, 2, 251.

BIS. (2012). Indian standards specification for drinking water. BIS, 10500, 2012.

Chatterjee, S. K., Bhattacharjee, I., \& Chandra, G. (2010). Water quality assessment near an industrial site of Damodar River India. Environmental Monitoring and Assessment. https://doi.org/10.1007/s1066 1-008-0736-1.

Chaturvedi, A., Bhattacharjee, S., Singh, A. K., \& Kumar, V. (2018). A new approach for indexing groundwater heavy metal pollution. Ecological Indicators, 87, 323-331. https://doi.org/10.1016/j.ecoli nd.2017.12.052.

Dhar, I., Biswas, S., Mitra, A., Pramanick, P., \& Mitra, A. (2020). COVID-19 Lockdown phase: A boon for the River Ganga water quality along the city of Kolkata. NUJS J Regulatory Studies, 26, 2456-4605.

George, J., Thakur, S. K. T., Ram, L. C., Gupta, A., \& Prasad, S. (2010). Impact of coal industries on the quality of Damodar river water. Toxicological \& Environmental Chemistry, 92(9), 1649-1664.

Ghosh, A. R., \& Banerjee, R. (2012). Qualitative Evaluation of the Damodar River water flowing over the coal mines and industrial area. International Journal of Scientific and Research Publications, 2, 10.

Hader, D. P., Banaszak, A. T., Villafane, V. E., Narvarte, M. A., Gonzalez, R. A., \& Helbling, E. W. (2020). Anthropogenic pollution of aquatic ecosystems: emerging problems with global implications. Science of the Total Environment, 713, 136586.

Hem, J. D. (1991). Study and interpretation of the chemical characteristics of natural water: USGS Professional Paper Book 2254 (p. 263). Jodhpur: Scientific Publishers.

Horton, R. K. (1965). An index number system for rating water quality. Journal of Water Pollution Control Federation, 37(3), 300-305.

Hossain, M., \& Patra, P. K. (2020). Water pollution index: A new integrated approach to rank water quality. Ecological Indicators, 117, 106668 .

Juwana, I., Muttil, N., \& Perera, B. J. C. (2012). Indicator-based water sustainability assessment-a review. Science of the Total Environment, 438, 357-371.

Liou, S. M., Lo, S. L., \& Wang, S. H. (2004). A generalized water quality index for Taiwan. Environmental Monitoring and Assessment, 96(1-3), 35-52.

Mani, K.S., (2020). The Lockdown Cleaned the Ganga More than' Namami Gange' Ever Did. [WWW Document]. https://science.thewire.in/environment/ganga-river-lockdown-cleaner-namami-gange-sewag e-treatment-ecological-flow/

Mitra, A., Pramanick, P., Zaman, S., Mitra, A., (2020). Impact of COVID-19 Lockdown on the Ichthyoplankton community in and around Haldia Port-cum-Industrial complex. NUJS Journal of Regulatory Studies, 57-61.

Mohan, S. V., Nithila, P., \& Reddy, S. J. (1996). Estimation of heavy metals in drinking water and development of heavy metal pollution index. Journal of Environmental Science, 31(2), 283-289.

Mukherjee, D., Dora, S. L., \& Tiwary, R. K. (2012). Evaluation of water quality index for drinking purposes in the case of Damodar River, Jharkhand and West Bengal Region India. Journal of Bioremedical and Biodegradation, 3(9), 2155-6199. https://doi.org/10.4172/2155-6199.1000161.

Mukherjee, P., Pramanick, P., Zaman, S., \& Mitra, A. (2020). Eco- restoration of River Gsanga water quality during COVID-19 lockdown period using total coliform (TC) as proxy. NUJS Journal of Regulatory Studies, 56, 2456-4605.

Pesce, S. F., \& Wunderlin, D. A. (2000). Use of water quality indices to verify the impact of Córdoba City (Argentina) on Suquía River. Water Research, 34(11), 2915-2926. 
Singh, A., Deo, B., \& Singh, S. P. (2014). Risk analysis on the use of Damodar River water for drinking purposes. International Journal of Current Engineering and Technology, 4(1), 560.

Sundararajan, M., \& Mohan, A. (2011). A study on the impact of coalwashery effluents along Damodar river stretch in Dhanbad district, Jharkhand, India. International Journal of Engineering and Management Science, 2(4), 135.

Swamee, P. K., \& Tyagi, A. (2000). Describing water quality with aggregate index. Journal of Environmental Engineering, 126(5), 451-455.

TiwaryAbhishek, R. K. (2005). Impact of coal washeries on water quality of Damodar River in Jharia coalfield. Indian J Environment protection, 25, 518522.

Tiwary, R. K., \& Dhar, B. B. (1994). Environmental pollution from coal mining activities in Damodar River Basin India. Mine Water and the Environment, 13, 1-10.

Tsegaye, T., Sheppard, D., Islam, K. R., Tadesse, W., Atalay, A., \& Marzen, L. (2006). Developmentofchemicalindexasameasureofin-streamwaterqualityinresponseto land-use and land cover changes. Water, Air, and Soil pollution, 174(1-4), 161-179.

WHO. (2011). Guidelines for drinking-water quality (4th ed.). Geneva: World Health Organization.

Yunus, A. P., Masago, Y., \& Hijioka, Y. (2020). COVID-19 and surface water quality: Improved lake water quality during the lockdown. Science of the Total Environment, 731, 139012. https://doi.org/10.1016/j. scitotenv.2020.139012.

Publisher's Note Springer Nature remains neutral with regard to jurisdictional claims in published maps and institutional affiliations.

\section{Affiliations}

\section{Baisakhi Chakraborty ${ }^{1}$. Sambhunath Roy ${ }^{1}$ - Amit Bera ${ }^{2}$ - Partha Pratim Adhikary ${ }^{3}$. Biswajit Bera ${ }^{4} \cdot$ Debashish Sengupta $^{5}$. Gouri Sankar Bhunia ${ }^{6} \cdot$ Pravat Kumar Shit $^{1}$}

Baisakhi Chakraborty

bchakraborty201595@gmail.com

Sambhunath Roy

sambhuroynath95@gmail.com

Amit Bera

amit.rs2017@geology.iiests.ac.in

Partha Pratim Adhikary

Partha.Adhikary@icar.gov.in

Biswajit Bera

biswajitbera007@gmail.com

Debashish Sengupta

dsgg@gg.iitkgp.ac.in

Gouri Sankar Bhunia

rsgis6gouri@gmail.com

1 PG Department of Geography, Raja N. L. Khan Women's College (Autonomous), Gope Palace, Midnapore, West Bengal 721102, India

2 Department of Earth Sciences, Indian Institute of Engineering Science and Technology, Shibpur, West Bengal, India

3 ICAR Indian Institute Water Management, Bhubaneswar, Odisha 751023, India

4 Department of Geography, Sidho Kanho Birsha University, Purulia, India

5 Department of Geology \& Geophysics, Indian Institute of Technology (IIT), Kharagpur, West Bengal 721302, India

6 Seacom Skill University, Birbhum, West Bengal, India 